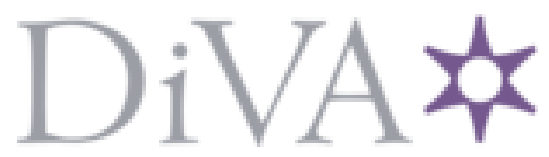

http://www.diva-portal.org

\title{
Preprint
}

This is the submitted version of a paper published in Journal of Paleontology.

Citation for the original published paper (version of record):

Holmer, L., Popov, L., Bassett, M. (2014)

Ordovician-Silurian Chileida—first post-Cambrian records of an enigmatic group of Brachiopoda.

Journal of Paleontology, 88(3): 488-496

http://dx.doi.org/10.1666/13-104

Access to the published version may require subscription.

N.B. When citing this work, cite the original published paper.

Permanent link to this version:

http://urn.kb.se/resolve?urn=urn:nbn:se:uu:diva-224297 
ORDOVICIAN-SILURIAN CHILEIDA - FIRST POST-CAMBRIAN RECORDS OF AN ENIGMATIC GROUP OF BRACHIOPODA

\author{
LARS E. HOLMER ${ }^{1}$, LEONID POPOV ${ }^{2}$ AND MICHAEL G. BASSETT ${ }^{2}$ \\ ${ }^{1}$ Department of Earth Sciences, Palaeobiology, Uppsala University, SE-752 36 Uppsala, Sweden, \\ <lars.holmer@pal.uu.se>, \\ ${ }^{2}$ Department of Geology, National Museum of Wales, Cardiff CF10 3NP, United Kingdom, \\ <leonid.popov@museumwales.ac.uk; mike.bassett@museumwales.ac.uk>
}

ABSTRACT- Brachiopods of the order Chileida have been recorded previously only from rocks of Early to Mid-Cambrian age (Botomian - Amgaian). They are typified by having a calcareous strophic shell with a delthyrium and colleplax, and these characters are shown to be present in species of the two new genera Tolen and Trifissura, from the Late Ordovician of Kazakhstan and the Silurian of Sweden and Britain, respectively. In specimens of Trifissura, the triangular colleplax is phosphatized secondarily by bacterial activity. It is suggested that the phosphatized colleplax represents an organic pad and that served as the original attachment structure of Trifissura by encrustation. Tolen and Trifissura represent the first post-Cambrian record of chileides from the Ordovician and Silurian; the new family Trifissuridae forms the first phylogenetic link between Cambrian chileides and Carboniferous - Permian isogrammides. 
INTRODUCTION

THE ORDER Chileida Popov and Tikhonov, 1990, was previously known only from the Early Cambrian (Botomian) to Mid Cambrian (Amgaian), whilst brachiopods belonging to the order Dictyonellida Cooper, 1956, are known from the Late Ordovician to the Late Permian (Popov et al., 1996; Popov and Holmer, 2000). The chileides includes some of the stratigraphically oldest known brachiopods with a calcareous and strophic shell. The most remarkable morphological feature of the chileides is that they are provided with large ventral umbonal perforation anterior to the umbo. This subtriangular perforation is enlarged by resorption and sometimes covered posteriorly by a colleplax (Wright, 1981), and Williams et al. (1996) included all known brachiopods with this morphology in the rhynchonelliform class Chileata Williams, Carlson, Brunton, Holmer and Popov, 1996.

Here we describe the first three known Ordovician-Silurian species of chileide brachiopods with an umbonal perforation and colleplax, referred to the new family Trifissuridae, and comprising the two new genera Trifissura and Tolen. The two new species Trifissura rigida and Tolen multicostatus are described. The ventral valve of Trifissura is provided with a thick phosphatic plug covering the umbonal perforation, and it is interpreted as the secondarily phosphatized remains of an originally organic attachment structure.

The exact phylogeny position of the Chileida and related groups is still poorly understood (Popov et al., 1996), and the position of the trifissurides need to be further investigated. However, Trifissura and Tolen clearly provide an important first phylogenetic link between the Cambrian chileides and the Carboniferous - Permian Isogrammidae. 
MATERIAL AND FOSSIL LOCALITIES

The described three brachiopod species assigned to the Trifissuridae were collected from localities in Kazakhstan, Sweden and England. The age range is from the Upper Ordovician Katian Stage to the Llandovery (?) and Wenlock Series of the mid Silurian. As yet there is no record from the intervening Hirnantian Stage.

Kazakhstan. - The new genus and species Tolen multicostatus is the oldest known record of the Trifissuridae, from the upper Ordovician (Katian) of Kazakhstan. It occurs sparsely in the upper part of the Akdombak Formation, Chokpar Regional Stage (late Katian) within the Ordovician-Silurian boundary section exposed west of the Tolen River in the Chingiz Range (locality 1783/1964 of O. P. Kovalevsky). The locality and stratigraphy is further described in Popov and Cocks (In press) and the occurrence of To. multicostatus is within the lower part of 'Unit T9'.

The associated fauna includes the trilobite Pliomerina sp., tabulate corals, and brachiopods characteristic of the Holorhynchus giganteus beds. Within the Ashgill Series, the Holorhynchus fauna is now known from boreholes in the East Baltic to immediately pre-date the widespread late Ashgill Hirnantian fauna (Rong et al., 2004).

Sweden. - The new genus and species Trifissura rigida occurs only on the Baltic island of Gotland, where all known specimens come from loose pebbles (old collections deposited in Naturhistoriska Riksmuseet, Stockholm) of greyish-blue nodules in the general coastal area north of Visby. The lithology of the nodules indicates that they most likely come from the upper Llandovery (?) - lower Wenlock Lower Visby Formation, and fairly certainly at or very close to the beach at Norderstrand (see Hedström, 1910, p. 1464; Jaanusson, 1986, p. 6), from where 
excellent outcrops of the Lower Visby Formation have been known historically. As noted by Jaanusson (1986, p. 6) the Norderstrand outcrops have been inaccessible for many years.

England. - Tr. transversa (Salter in Davidson, 1866) is the youngest known member of the Trifissuridae, and all available material come from the mid Silurian, Wenlock (Homerian), Coalbrookdale Formation of the West Midlands (Cocks, 1978, p. 21), preserved in old museum collections (see list below). Most specimens are from now inaccessible old outcrops in the general neighbourhood of Wrens Nest National Nature Reserve, Dudley and Walsall (see, e.g. Davidson, 1853; Ray et al., 2011) or just from unspecified localities at "Dudley" as well as from temporary localities probably in connection with work on the Malvern and Ledbury tunnels, the Malvern Hills.

Abbreviations and locations of the museums holding type and studied material are as follows: BGS, British Geological Survey, Keyworth, Nottinghamshire; NHM, Natural History Museum, London; OUM, Oxford University Museum; RM, Naturhistoriska Riksmuseet, Stockholm; SM, Sedgwick Museum, Cambridge.

\section{SHELL MORPHOLOGY}

The brachiopods of the new family Trifissuridae are characterized by having strongly transverse, compressed, biconvex strophic shells. Notwithstanding the presence of a straight hinge line there is no evidence of any articulatory device. All studied specimens are preserved as compressed internal and external or composite moulds in limestones or in argillaceous mudrocks. In characters of preservation, the specimens of Trifissura rigida from Gotland occur in similar preservation to gastropods from the same nodules at the same locality, with neomorphosed shells or as moulds, whereas orthides and atrypides from the same samples retain 
an unaltered calcitic shell. In the British material, Tr. transversa is also preserved as internal and external moulds, whereas the calcitic shells of trilobites and rhynchonelliform brachiopods from the same samples are not affected by dissolution or neomorphism. These observations strongly support the interpretation that the shell in trifissurides was originally aragonitic, as in trimerellide brachiopods (Jaanusson, 1966; Balthasar et al., 2011). Valves of trifissurides were thin marginally, but somewhat thickened under the visceral areas of both valves, where phosphatic pads are commonly preserved in the umbonal area and under the muscle scars.

Some specimens of Tr. transversa preserve a thin phosphatic veneer bearing distinct pitted ornament, with circular depressions around $300 \mu \mathrm{m}$ across (Fig. 1.2). SEM study reveals that the veneer consists of dense, irregular phosphatic filaments about 2-4 $\mu \mathrm{m}$ wide (Fig. 1.3, 1.4). These filaments are comparable to cyanobacterial sheaths (e.g., Goncharova et al., 1993). It is most probable that this phosphatic veneer is a cast of the originally organic periostracum, phosphatised secondarily by bacterial activity.

The ventral valve of trifissurides is characterised by mixoperipheral growth, with a wide, flat, almost orthocline interarea bearing a narrow triangular delthyrium covered by the convex pseudodeltidium (Fig. 2). The poor imprints of the shell surface in the moulds make it difficult to determine the nature of the shell growth in the dorsal valve. Along the straight dorsal posterior margin there is a wide, flattened area, covered by closely spaced growth lines in Tr. transversa (Fig. 3.2, 3.4). This area can be seen as a simple thickening of the posterior margin that was composed exclusively of secondary shell. If this scenario is valid, the shell growth of the dorsal valve of trifissurides was hemiperipheral as in chileides. However, it could also be formed as a result of normal accretionary growth, including secretion of a primary shell by the posterior dorsal mantle lobes, but this is difficult to determine. 
Radial ornament is characteristic only of the Ordovician trifissuride Tolen. It comprises low, fine bifurcating ribs, which are curved posteriorly in the posterolateral areas of the shell to cross the hinge line. The inner surface of the shell shows the presence of follicular embayments along the shell margins, suggesting the former presence of marginal setae.

Interiors of both valves are usually weakly impressed, but the visceral area is usually easily recognizable (Figs. 2.3-4, 3.5-6, 4). In the ventral valve it is usually bordered posterolaterally by a distinct rim, which is most pronounced in Tr. rigida. This rim may have supported outside lateral muscles similar to those of craniides, and which were attached anteriorly to the body wall and used for the hydraulic opening of the shell. Paired muscle scars along the lateral sides of the visceral area represent the posterior adductors (Figs. 2.3, 2.4, 4.3). They are usually accentuated by symmetrically placed phosphatic pads that are interpreted as having developed on the organic membranes within the shell underlying the muscles. Large ventral anterolateral scars, which are usually weakly impressed to almost unrecognisable, may represent combined attachment scars of the anterior adductors and internal oblique muscles (Figs. 2.4, 4.3). In the dorsal valve, internal oblique muscles were attached to the thickened callus developed in the posteromedian part of the visceral area, whereas posterior adductor scars are usually accentuated by the rim bounding them posterolaterally (Figs. 3, 5.6). Anterior adductor scars in Trifissura are usually weakly impressed, but in Tolen they are situated on a callus of secondary shell, and bounded laterally by a low rim. The anteromedian region of the dorsal visceral area in Tolen also has a small elevated muscle platform, which probably supported the brachial protractors.

Mantle canals in trifissurides are best preserved in Tr. rigida. They are pinnate in both valves, whereas coarsely tuberculate areas in the posterolateral areas of the valves suggest the position of 
vascula genitalia. In Tr. transversa mantle canals are observed only in the ventral valve, where they represent paired, anteriorly directed vascula media and vascula lateralia (Fig. 4.1, 4.4).

\section{ATTACHMENT STRUCTURES}

The ventral valve of trifissurides bears a triangular opening anterior to the umbo, which is enlarged anteriorly due to resorption of surrounding shell and is covered umbonally by a plate. This plate is interpreted here as a colleplax, and representing part of an attachment structure that is homologous to that of chileides and dictyonellides. An unusual feature of the colleplax in the Trifissuridae is the constant presence of a thick phosphatic plug covering the opening. The plug consists of numerous lamellae varying in thickness from 100 to $500 \mu \mathrm{m}$, directed slightly obliquely and overlapping each other in an anterior direction (Fig. 1.5, 1.8, 1.9, 12). In cross section, the external surface of these lamellae is uneven, suggesting that they were originally organic and growing over a hard ground, probably representing bioclasts (Fig. 1.5, 1.6). The original fine structure in these lamellae is generally not preserved, but is replaced by aggregates of irregular, tubular, phosphatic filaments about 2-4 $\mu$ m wide (Fig. 1.9, 1.11) similar to those described above as probable casts of the periostracum. Some shells of Trifissura rigida show a different preservational pattern. In these specimens, the phosphatic pad covering the colleplax consists of dense, almost parallel solid fibers only about 1-2 $\mu \mathrm{m}$ wide running subparallel to the shell surface (Fig. 1.7, 1.10). Each fiber is built of a bunch of fibrils $100 \mathrm{~nm}$ across. These characters suggest a fine phosphatization of an original organic tissue, which may have been similar in composition to that of the periostracum, but functioning as a sticky organic pad (in the sense of Wright, 1981) by which the trifissurides were attached to the substrate. 
However, it is also conceivable that the phosphatic pad in Trifissura is the remains of the basal proximal portion of an elongated attachment structure, where the distal parts have not been preserved. The exceptionally preserved elongated attachment structure of the chileide Longtancunella from the early Chengjiang Lagerstätte is composed of numerous stacked pads emerging from a perforation and colleplax structure (Zhang et al., 2011).

\section{SYSTEMATIC POSITION OF THE NEW FAMILY TRIFISSURIDAE}

The family Trifissuridae includes only the two new genera Trifissura and Tolen with the two new species: Tr. rigida and To. multicostatus as well as Tr. transversa (Salter in Davidson, 1866). All these taxa have very simple shell morphology, and they are inarticulated. Therefore, it is not surprising that the only previously described species Tr. transversa was assigned initially to the Trimerellida. However, trifissurides differ from all known trimerellides in the absence of thickened muscle platforms in both valves and in the possession of a dorsal median ridge. They also have a narrow delthyrium covered by a convex pseudodeltidium. Moreover, they lack the trimerellide type articulation, and most likely retained a hydraulic shell-opening mechanism. The presence of a ventral umbonal perforation enlarged by resorption, in combination with a welldefined ventral interarea bearing a pseudodeltidium, a strophic shell lacking articulatory structures, and possible hemiperipheral growth of the dorsal valve, are known also in the early Cambrian family Chileidae and can be considered as diagnostic for the attribution of trifissurides to the order Chileida (Popov and Holmer, 2000; see also Holmer et al., 2009, 2011).

The shell structure of chileides is known only for the late Early Cambrian Kotujella (family Matutellidae) from Siberia (Williams and Cusack, 2007), whereas all other taxa are known only 
from silicified material. According to Williams and Cusack (2007), the Cambrian chileides have a calcitic endopunctate shell with a foliated secondary layer. However, characters of preservation of the shell in the Trifissuridae suggest significant differences in shell composition and structure by comparison with the Cambrian taxa, justifying their attribution to a separate new family.

Among chileates, the late Palaeozoic family Isogrammidae (order Dictyonellida) may also have had an aragonitic shell (Popov and Holmer, 2000). Isogrammides are characterised also by having a transverse strophic shell, and in having a colleplax, but they differ in having an open delthyrium, rudimentary articulation, and a cardinal process that suggests the presence of muscles acting as diductors. There is a possibility that isogrammides are more closely related phylogenetically to trifissurides casting doubt on the status of the order Dictyonellida, but this relationship requires further study.

\title{
SYSTEMATIC PALAEONTOLOGY
}

Morphological terminology and taxonomic classification follow Popov and Holmer (2000).

\author{
Class ChILEATA Williams, Carlson, Brunton, Holmer and Popov, 1996 \\ Order CHILEIDA Popov and Tikhonov, 1990 \\ Family TRIFISSURIDAE new family
}

Diagnosis.- Shell biconvex, transversely oval, with wide, straight posterior margin; anterior commissure rectimarginate; ventral valve with mixoperipheral growth; ventral interarea low and wide, divided by narrowly triangular delthyrium and convex pseudodeltidium; ventral umbonal 
area perforated by subtriangular opening, becoming enlarged by shell resorption, and covered by colleplax; dorsal valve with mixoperipheral or hemiperipheral growth; dorsal interior with slightly raised, elongate, suboval visceral area bounded by rim; muscle system with two pairs of adductors and paired internal oblique muscles attached dorsally to the thickened, semioval plate in the median part of the posterior margin; mantle canal system pinnate in both valves; shell fabric possibly originally aragonitic.

Remarks. - The Trifissuridae n. fam. are closely comparable with the Isogrammidae in having a transverse, flattened shell exhibiting hemiperipheral growth of the dorsal valve and a colleplax in the umbonal region of the ventral valve. However, the new family can be distinguished by the absence of a cardinal process, and in having a weakly developed median ridge, with a delthyrium covered apically by a convex pseudodeltidium. In having the large opening anterior to the ventral umbo, and a narrow triangular delthyrium covered apically by a convex pseudodeltidium. Members of the Trifissuridae are also somewhat similar to the family Chileidae, but differ from the latter in having the colleplax completely covering the ventral umbonal opening.

Presently only the two new genera Trifissura and Tolen are included, but the phylogenetic position of the morphologically similar Gasconsia Northrop, 1939, is uncertain. Gasconsia lacks all evidence of a chileide ventral umbonal perforation and colleplax, but has a straight posterior margin and clearly lack the trimerellide type articulation and musculature (Hanken and Harper, 1985; Merg1, 1989, Popov et al., 1997). 
Type species. - Obolus davidsoni var. transversus Salter in Davidson, 1866; Silurian, Wenlock, Homerian, Coalbrookdale Formation; West Midlands.

Other species. - Trifissura rigida $\mathrm{n}$. sp.

Diagnosis. - Trifissuridae with dorsal muscle platforms weakly developed, bisected by a low median ridge separating shallow umbonal cavities.

Etymology. - From Latin, fissura, a crack or cleft, and triangular, referring to the triangular colleplax.

Occurrence. - Silurian, Llandovery (?) - Wenlock, of Sweden and Britain.

Remarks. - Trifissura differs from the problematic Gasconsia mainly in having an umbonal perforation and colleplax as well as in the lack of solid visceral platforms.

TRIFISSURA TRANSVERSA (Salter in Davidson, 1866)

Figures $1.1-5,8,9,11,12 ; 2-4$

1866 Obolus davidsoni var. transversus [SALTER MS] DAVIDSON; p. 59, pl. 5, figs. 1-6. 1874 Dinobolus transversus (Salter), DAVIDSON AND KING, p. 163, pl. 18, fig. 12.

Diagnosis. - Trifissura with moderately dorsibiconvex shell, with large colleplax, and dorsal median ridge extending for about two-fifth of valve length, separating shallow umbonal cavities; ventral mantle canals with paired vascula media and vascula lateralia.

Description. - Shell slightly dorsibiconvex, transversely suboval in outline, on average 70\% as long as wide (observed range $55-98 \%, \mathrm{~N}=31$ ) and about two-fifth as thick as long in one 
specimen. Hinge line straight, about three-fourth as wide as maximum shell width at midlength. Anterior commissure rectimarginate. Ventral valve gently and evenly convex, on average $37 \mathrm{~mm}$ long (observed range 26-58 mm, N=20) and $53 \mathrm{~mm}$ wide (observed range 34-74 mm, $\mathrm{N}=20$ ), with a low, planar almost orthocline interarea divided by narrow, triangular delthyrium, covered apically by convex pseudodeltidium (Fig. 2.2, 2.3). Umbonal area with slightly elongate, subtriangular colleplax, on average $142 \%$ as long as wide (observed range $102-176 \%, \mathrm{~N}=20$ ) and occupying on average $16 \%$ of total width of valve (observed range $11-30 \%, \mathrm{~N}=20$ ) and $23 \%$ of total length of valve (observed range $15-42 \%, \mathrm{~N}=20$ ), sealed by phosphatic pad. Dorsal valve on average $38 \mathrm{~mm}$ long (observed range $27-55 \mathrm{~mm}, \mathrm{~N}=11$ ) and $56 \mathrm{~mm}$ wide (observed range 38$76 \mathrm{~mm}, \mathrm{~N}=11$ ), moderately convex, with lateral profile more strongly curved in posterior onethird valve length. Shell surface smooth with fine, regular filae (Figs. 2,3); periostracum rarely preserved by secondary phosphatization, with pitted micro-ornament (Fig. 1.2).

Ventral interior with weakly impressed visceral area. Anterior adductor muscle scars situated on anterior termination of paired linear muscle tracks and often accentuated by secondary phosphatization and placed laterally to colleplax (Fig. 2.2). Posterolateral parts of ventral visceral area occupied by callus of secondary shell, representing attachment scars of the anterior adductors and oblique lateral muscles. Ventral mantle canals weakly impressed with thin straight closely spaced, subparallel vascula media in medial part of valve and broad, anteriorly directed vascula lateralia (Fig. 4.1, 4.4). Dorsal interior with weakly impressed posterior and anterior adductor scars (Fig. 4.3, 4.6); median ridge low, broad extending for about two fifth of total valve length and bisecting both visceral area and a pair of shallow umbonal cavities (Fig. 4.5, 4.6). 
Lectotype. - Selected by Cocks (1978, p. 21), NHM B.5941, Silurian, Homerian, Coalbrookdale Formation; "Parkes Hall” (variably referred to, e.g., as "Park Hall” in Davidson and King 1874, p. 163; possibly from temporary exposures close to the present location of the Parkes Hall Pool), Dudley, West Midlands.

Other material. - Dudley (unspecified localities); conjoined valves: NHM B.280a, OUM C.20395, NHM BB97704; ventral valves: SM A.12281, SM A.13255, NHM B.280b, NHM B.280d, NHM B.3658, NHM B.9480; dorsal valves: SM A.12280, NHM B.1104, SM A13279; NHM B.280c), NHM B.280e-g, NHM B3658. "Parkes Hall”, Dudley, West Midlands; NHM BB.34720, dorsal valve. Ledbury, Malvern (collected by R.B. Grindrod): ventral valves: OUM C.20386, OUM C.20387, OUM C.20389, C.20392, OUM C.20393, OUM C.20397, OUM C.20399), OUM C.20400, OUM C.20401, OUM C.20403, OUM C.20404, OUM C.20407, OUM C.20408, C.20412, C.20413, NHM B.3658, NHM B3923; dorsal valves: OUM C.17817, OUM C.20394, OUM C.20398, OUM C.20402, OUM C.20405, OUM C.20409, OUM C.20410. May Hill, Malvern; BGS 16513, dorsal valve. Knapp Lane, Malvern (collected by Piper, G. H., 1898); NHM B.16859, dorsal valve. Ledbury Tunnel, Malvern; NHM B.16860, ventral valve. Walsall (collected by J, Grey, 1898); NHM B1104, ventral valve.

Remarks. - Most of the studied specimens are deformed and compressed in various degrees, and frequently the preservation is a complex combination of composite external/internal moulds. Therefore described characters of the internal shell morphology are mostly based on a few threedimensionally preserved internal moulds (Fig. 4). Gasconsia transversus described by Watkins (2002) from the late Silurian (Ludlow) of the Welsh Borderland seemingly lacks all evidence of an umbonal perforation and colleplax; most likely it is not conspecific with Trifissura transversa. 


\section{TRIFISSURA RIGIDA new species}

Figures 1.6, 7, 10; 5.4-10

Diagnosis. - Trifissura with flattened shell, smooth; colleplax small, not extending to midvalve; mantle canals of both valves pinnate.

Description. - Shell flattened, smooth, only slightly biconvex, transversely suboval, on average $71 \%$ as long as wide (observed range $60-78 \%, \mathrm{~N}=6$ ), with strophic posterior margin, shorter than maximum shell width. Anterior commissure rectimarginate. Ventral valve 22-30 $\mathrm{mm}$ long and 31-41 $\mathrm{mm}$ wide in three specimens, only slightly convex in transverse and lateral profile, with flattened rim around margin. Colleplax almost triangular, $129-155 \%$ as long as wide and occupying $14-47 \%$ of total width of valve and $21-68 \%$ of total length of valve in three specimens. Surface of colleplax uneven, ornamented by undulating growth lamellae and slightly elevated above surrounding shell. Dorsal valve with hemiperipheral growth, only slightly convex with flattened rim around margin.

Ventral visceral area, extending anteriorly about $55-60 \%$ of total valve length, bordered posterolaterally by an elevated rim. Dorsal interior with visceral area extending anteriorly about $60-65 \%$ of total valve length, and bordered posterolaterally by rim. Dorsal internal oblique muscle scars situated on high transverse ridge, undercut anteriorly present along posterior margin of dorsal visceral area. Dorsal median ridge very short, rapidly fading anteriorly, separating rudimentary umbonal cavities. Mantle canals pinnate with tuberculate impressions of vascula genitalia on posterolateral sides of both valves.

Etymology. - After Latin - rigidus, stiff, rigid, referring to the rigid shell. 
Holotype. - RM Br23486, internal mould of conjoined valves, Silurian, Llandovery (?) Wenlock, allochthonous boulder, "Visby" most likely Norderstrand.

Other material. - RM Br 23484, ventral valve; RM Br23485, dorsal internal mould; RM Br 23487, ventral internal mould; RM Br23216; RM Br23292, ventral internal mould; RM Br23279, dorsal internal mould.

Remarks. - This new species from Gotland differs from the type species, Trifissura transversa, in having distinct, pinnate mantle canals in both valves, as well as a short dorsal median ridge and rudimentary dorsal umbonal cavities.

\section{Genus TOLEN new genus}

Type species by monotypy. - Tolen multicostatus n. sp., from the Late Ordovician, Katian, upper Akdombak Formation (Holorhynchus giganteus Beds), Chingiz Range, Kazakhstan.

Diagnosis. - Trifissuridae with triangular colleplax extending to mid-valve length, slightly raised slightly above outer surface; dorsal valve with radial ornament of low, bifurcating ribs; dorsal valve lacking median ridge and umbonal cavities, with paired anterior adductor and brachial protractor muscle scars thickened and bounded by high rim.

Etymology. - Referring to the Tolen River, near the type locality.

Occurrence. - Late Ordovician of Kazakhstan.

Remarks. - Tolen n. gen. differs from Trifissura n. gen. in having a well-developed costellate radial ornament and a large colleplax extending to mid-valve length, and in having raised anterior adductor and brachial protractor muscle scars bounded by a rim, as well as in the complete absence of a dorsal median ridge and umbonal cavities. 


\section{TOLEN MULTICOSTATUS new species}

Figure 5.1-3

Diagnosis. - Shell transverse, strophic, subequally biconvex; ventral valve with triangular colleplax extending to mid-valve length, slightly raised slightly above outer surface; dorsal valve with hemiperipheral growth; radial ornament of low, bifurcating ribs curved posteriorly towards hinge line; dorsal interior with paired anterior adductor and brachial protractor muscle scars situated on thickened callus of secondary shell and bounded anteriorly and laterally by high rim.

Description. - Shell gently and subequally biconvex, transversely suboval, about $80 \%$ as long as wide, with strophic posterior margin occupying about $75 \%$ of maximum shell width. Anterior commissure rectimarginate. Ventral valve $23 \mathrm{~mm}$ long and $30 \mathrm{~mm}$ wide in one specimen, gently and evenly convex in transverse and lateral profile. Colleplax almost triangular, about twice as long as wide, originating at the marginal umbo and extending to mid-valve length. Surface uneven, ornamented by undulating growth lamellae, and slightly raised above surrounding shell surface. Dorsal valve $25 \mathrm{~mm}$ long and $32 \mathrm{~mm}$ wide in holotype, gently and evenly convex with hemiperipheral growth. Radial ornament costellate, with low rounded, bifurcating ribs about 3-4 per $3 \mathrm{~mm}$ along the anterior margin. Ribs separated by wide interspaces and curved posteriorly towards hinge line in posterolateral parts of the shell. Concentric ornament of evenly spaced filae, about 3 per $1 \mathrm{~mm}$.

Ventral interior unknown. Dorsal interior with visceral area extending anteriorly to about $70 \%$ of total valve length and bordered anterolaterally by rim. Anterior adductor scars large, elongate suboval, situated at about mid-valve. Brachial protractors on thick callus of secondary 
shell, situated near anterior termination of visceral area, anterior to mid-valve. Posterior adductors weakly impressed, situated close to posterior margin and bordered laterally by low rim.

Etymology. - Referring to the multicostate radial ornament.

Holotype. - NMW 2001.38G.801, dorsal external mould; Upper Ordovician, Katian, Akdombak Formation, sample 1783, Tolen River, Bakanas river basin, Chingiz Range, Kazakhstan.

Other material. - NMW 2001.38G.801, ventral external mould.

\section{ACKNOWLEDGMENTS}

The work of Lars Holmer was supported by grants from the Swedish Research Council (VR 2009-4395, 2012-1658). Leonid Popov and Michael Bassett acknowledge logistical and financial support from the National Museum of Wales. Michael Bassett's work on Gotland is supported by the Leverhulme Trust. Thanks are also due to Christina Franzén (Stockholm) and Christian Skovsted (Stockholm) for loan of material and assistance. We are grateful to the editor, Brian Pratt (Saskatoon) and the referees for comments that improved the manuscript.

\section{REFERENCES}

Balthasar, U., M. Cusack, L. Faryma, P. Chung, L. E. Holmer, J. Jin, I. G. Percival, And L. E. POPOV. 2011. Relic aragonite from Ordovician-Silurian brachiopods: Implications for the evolution of calcification. Geology, 39:967-970.

Cocks, L. R. M. 1978. A review of British Lower Palaeozoic brachiopods, including a synoptic 
revision of Davidson's monograph. Palaeontographical Society Monograph, 131:1-256.

Cooper, G. A. 1956. Chazyan and related brachiopods. Smithsonian Miscellaneous Collections, $127: 1-1245$.

DAVIDSON, T. 1853. British fossil Brachiopoda, vol. I. Introduction. Palaeontographical Society Monograph, London, $136 \mathrm{p}$.

DAVIDSON, T. 1866. British fossil Brachiopoda, vol. III. Silurian, part 7, no. 1.

Palaeontographical Society Monograph, London, 88 p.

DAVIDSOn, T. AND W. King. 1874. On the Trimerellidae, a Palaeozoic family of the

Palliobranchs or Brachiopoda. Quarterly Journal of the Geological Society of London, $30: 124-172$.

Goncharova, I. V., L. M. Gerasimenko, G. A. Zavarzin, And G. T. Ushatinskaya. 1993. Formation of mineral phosphate microtubes in the presence of halophilic Cyanobacterium Microcoleus chthonoplastes. Current Microbiology, 27:187-190.

HANKEN, N. M., AND D. A. T. HARPER. 1985. The taxonomy, shell structure, and palaeoecology of the trimerellid brachiopod Gasconsia Northrop. Palaeontology 28:243-254.

Hedström, H. 1910. The Stratigraphy of the Silurian strata of the Visby district. Geologiska Föreningen i Stockholm Förhandlingar, 32:1455-1484.

Holmer, L. E., S. Pettersson Stolk, C. B. Skovsted, U. Balthasar, and L. Popov. 2009. The enigmatic Early Cambrian Salanygolina - a stem group of Rhynchonelliform Chileate Brachiopods? Palaeontology, 52:1-10,

Holmer, L. E., C. B. Skovsted, G. A. Brock, And L. E. Popov. 2011. An early Cambrian chileate brachiopod from South Australia and its phylogenetic significance. Memoir of the Association of Australasian Palaeontologists, 41:289-294. 
JAANUSSON, V. 1966. Fossil brachiopods with probable aragonitic shell. Geologiska

Föreningen i Stockholm Förhandlingar, 88:279-281.

JAANUSSON, V. 1986. Locality designations in old collections from the Silurian of Gotland, Department of Palaeozoology, Swedish Museum of Natural History, Stockholm, 19 p.

Mergl, M. 1989. Trimerellid brachiopods in the Silurian (Wenlock/Ludlow) in the Prague Basin (Central Bohemia). Věstník Ústředního ústavu geologického, 64:267-275.

NorThrop, S. A. 1939. Paleontology and stratigraphy of the Silurian rocks of the Port DanielBlack Cape Region, Gaspé. Geological Society of America, Special Paper 21, 302 p. POPOV, L. E., AND L. R. M. COCKS. In press. Late Ordovician brachiopods from the Chingiz Terrane, Kazakhstan, and their palaeogeography. Journal of Systematic Palaeontology. Popov, L. E. AND L. E. Holmer. 2000. Class Chileata, p. 193-196. In R. Kaesler (ed.). Treatise on invertebrate paleontology. Part H Brachiopoda (Revised) 2. Geological Society of America and University of Kansas Press, Boulder and Lawrence.

PopOV, L. E. AND J. A. TIKHONOV. 1990. Rannekembriiskie brakhiopody iz yuzhnoi Kirgizii. [Early Cambrian brachiopods from southern Kirgizia.]. Paleontologicheskii Zhurnal, 3:3346.

Popov, L. E., L. E. Holmer, AND M. G. BASSETT. 1996. Radiation of the earliest calcareous brachiopods, p. 209-213. In P. Copper and J. Jin (eds.), Brachiopods, Proceedings of the Third International Brachiopod Congress Sudbury, Ontario, Canada, 2-5 September 1995. A. A. Balkema, Rotterdam, Brookfield.

POPOV, L. E., L. E. HolmER, AND V. Y. GORJANSKY. 1997. Late Ordovician and Early Silurian trimerellide brachiopods from Kazakhstan. Journal of Paleontology, 71:584-598.

Ray, D. C., A. V. J Collings, G. J. Worton, And G. Jones. 2011. Upper Wenlock bentonites 
from Wren's Nest Hill, Dudley; comparisons with prominent bentonites along Wenlock Edge, Shropshire, England. Geological Magazine, 148:670-681,

RONG J., R. ZHAN AND J. JIN. 2004. The Late Ordovician and Early Silurian pentameride brachiopod Holorhynchus Kiaer, 1902 from North China. Journal of Paleontology, 78:287299.

WATKINS, R. 2002. New record of the trimerellid brachiopod Gasconsia, a rare Silurian Lazarus taxon. Journal of Paleontology, 76:185-186.

Williams, A., S. J. Carlson, C. H. C. Brunton, L. E. Holmer, And L. E. Popov. 1996. A supra-ordinal classification of the Brachiopoda. Philosophical Transactions of the Royal Society of London, Series B, 351:1117-1193.

WiLliams, A. AND M. CUSACK. 2007. Chemostructural diversity of the brachiopod shell, 23962521. In Selden, P. A. (ed.). Treatise on Invertebrate Paleontology, Part H, Brachiopoda (Revised) 6. Geological Society of America and the University of Kansas Press, Boulder and Lawrence.

WRIGHT, A. D. 1981. The external surface of Dictyonella and other pitted brachiopods. Palaeontology 24:443-481.

Zhang, Z., L. E. Holmer, Q. QIANG, J. HAN, AND D. SHU. 2011. The exceptionally preserved Early Cambrian stem rhynchonelliform brachiopod Longtancunella and its implications. Lethaia, 44:490-495. 


\section{FIGURE CAPTIONS}

FIGURE 1. 1-6, 8, 6, 11, 12, Trifissura transversa (Salter in Davidson, 1866), Wenlock, Homerian, Coalbrookdale Formation; 1-4, BM B.1104, ventral valve, Walsall, 1, backscatter image of colleplax; 2-4, phosphatised periostracum showing pitted micro-ornament and aggregation of cyanobacterial filaments; 5, 8, 9, 11, 12, C20400, ventral valve, transverse section through the phosphatic pad covering the colleplax, 5, 11, microstructure showing aggregation of cyanobacterial filaments;. 6, 7, 10, Tr. rigida n. sp., Llandovery (?) - Wenlock, allochthonous boulder, "Visby", probably Norderstrand; RM Br 23486, back scatter image of colleplax showing dense, almost parallel fibres.

FIGURE 2. Trifissura transversa (Salter in Davidson, 1866), Wenlock, Homerian, Coalbrookdale Formation; 1, NHM B.5941, lectotype, ventral valve exterior, "Parkes Hall" (probably close to Parkes Hall pool), Dudley; 2, NHM B.820d, ventral internal mould, "Dudley" (unspecified); 3, NHM B.9480, external mould of conjoined valves, "Dudley" (unspecified); 4, BM B.1104, ventral valve, "Walsall" (unspecified) (abbreviations: a.a., anterior adductor scars; cl, colleplax; pd, pseudodeltidium); 5, 6, SM A13255a, b, ventral internal and external moulds, "Dudley" (unspecified). All scale bars are $5 \mathrm{~mm}$.

FIGURE 3. Trifissura transversa (Salter in Davidson, 1866); Silurian, Wenlock, Homerian, Coalbrookdale Formation; 1, 3, BGS 16513, latex cast of dorsal interior, dorsal internal mould, "May Hill", Gloucestershire; 2, 4, SM A13279, latex cast of dorsal valve interior, dorsal internal 
mould, Dudley; 5, 6, SM A13254, latex cast of dorsal valve interior, dorsal internal mould, Dudley. All scale bars are $5 \mathrm{~mm}$.

FIGURE 4. Trifissura transversa (Salter in Davidson, 1866), Wenlock, Homerian, Coalbrookdale Formation, "Dudley” (unspecified) (abbreviations: a.a., anterior adductors; p.a., posterior adductors; p.m., composite attachment scars of posterior adductors and outside oblique muscles; v.l., vascula lateralia; v.m., vascula media); 1-3, B820a, internal mould of conjoined valves, ventral, lateral and dorsal views; 4-6, B820b, internal mould of conjoined valves, ventral, lateral and dorsal views. All scale bars are $5 \mathrm{~mm}$.

FIGURE 5. 1-3, Tolen multicostatus n. sp.; Upper Ordovician, Katian, Akdombak Formation, sample 1783, Tolen River, Bakanas river basin, Chingiz Range, Kazakhstan; 1, 3, NMW 2001.38G.801, enlarged umbonal area and latex cast of ventral interior; 2, NMW 2001.38G.802, holotype, dorsal internal mould. 4-10, Trifissura rigida n. sp.; Llandovery (?) - Wenlock, allochthonous boulder, "Visby", probably Norderstrand; 4, RM Br23292, ventral internal mould; 5-6, RM Br 23486, holotype, internal mould of conjoined valves ventral and dorsal views; 7, RM Br23485, dorsal internal mould; 8, RM Br23279, dorsal internal mould; 9, RM Br 23487, ventral internal mould; 10, RM Br 23484, ventral internal mould. All scale bars, except in fig. 1.1 are 5 $\mathrm{mm}$. 

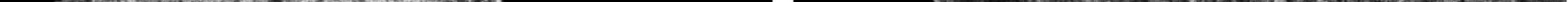


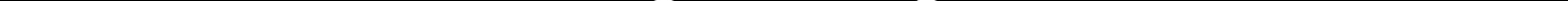



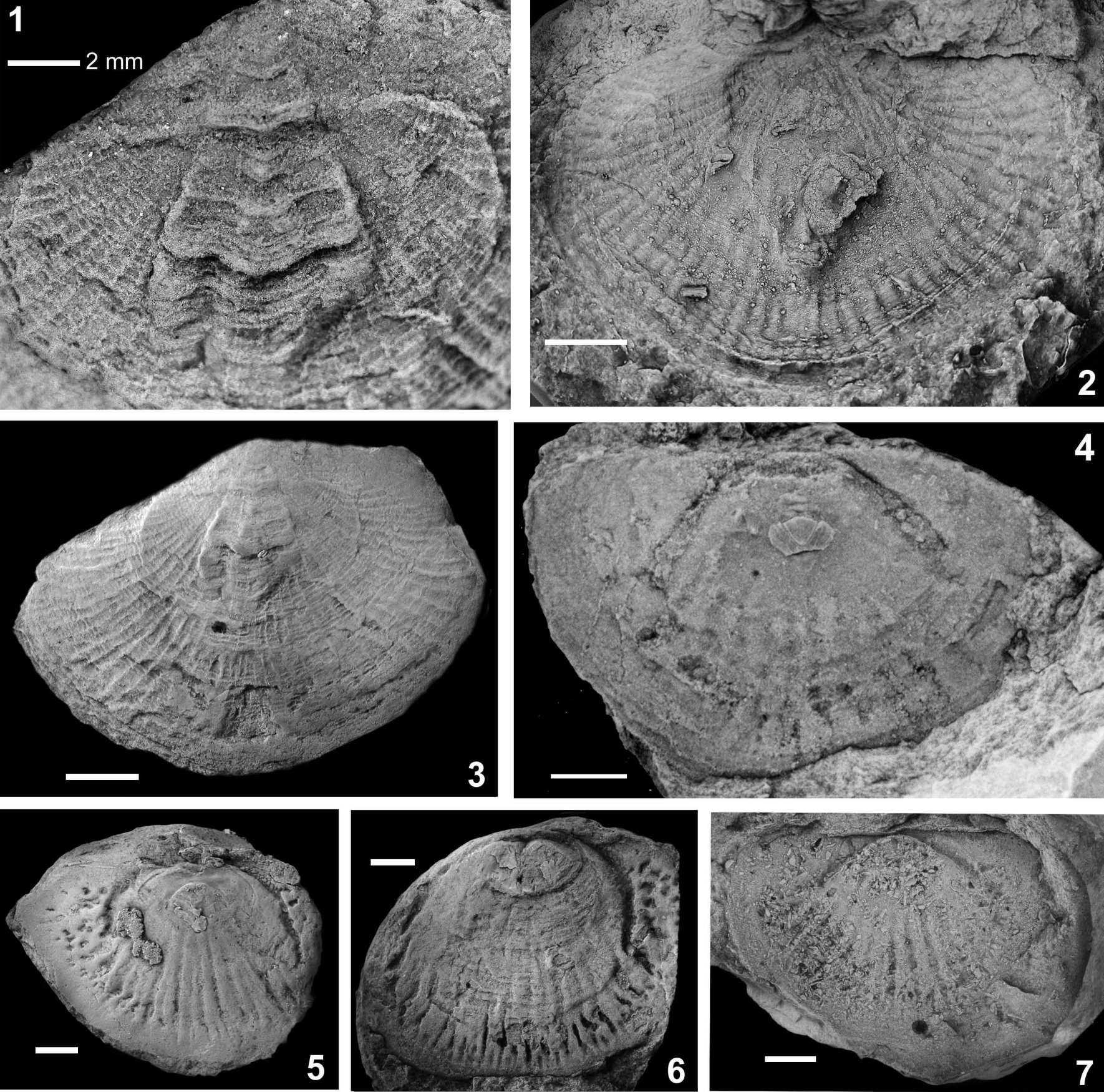

3
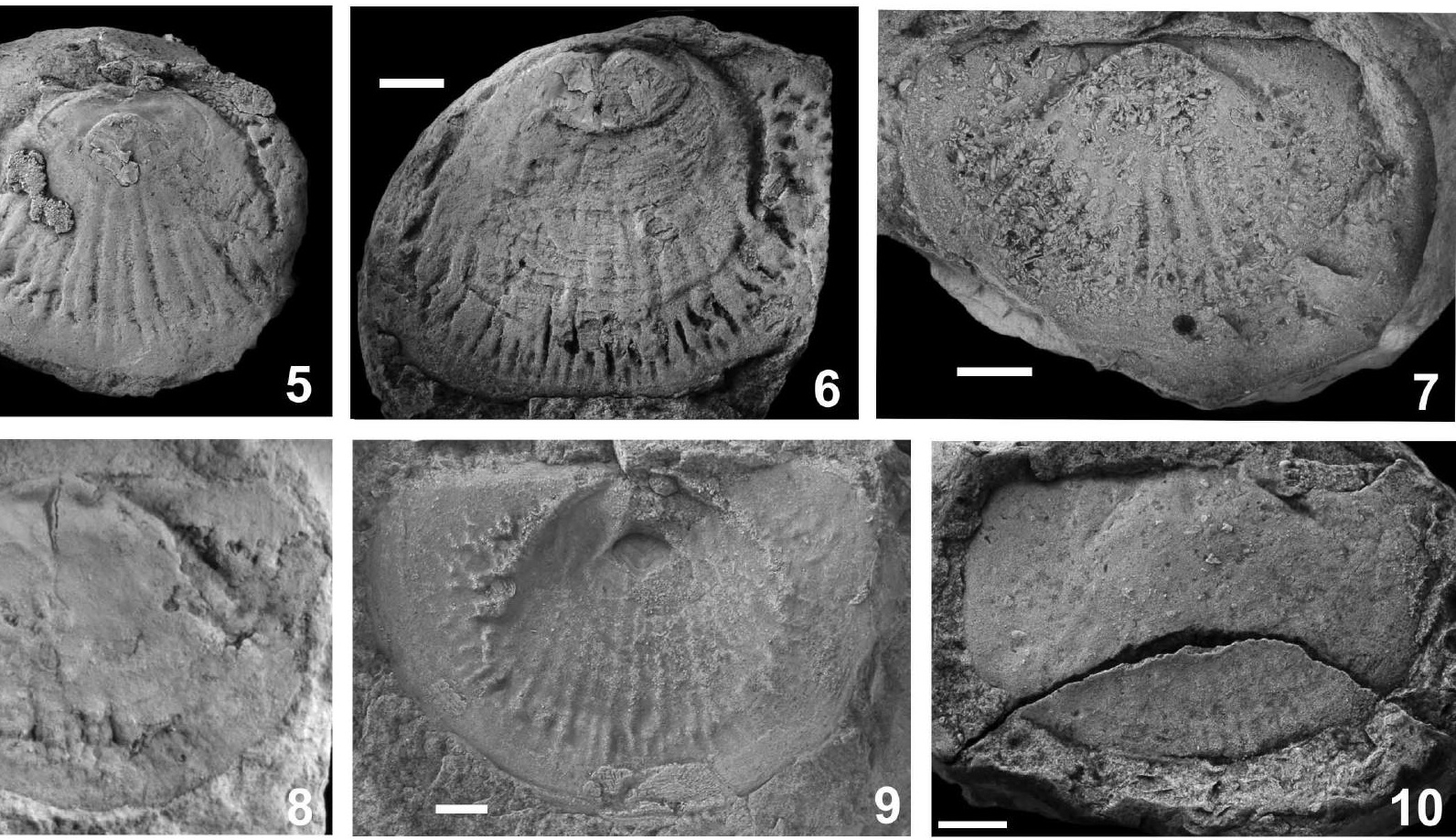